
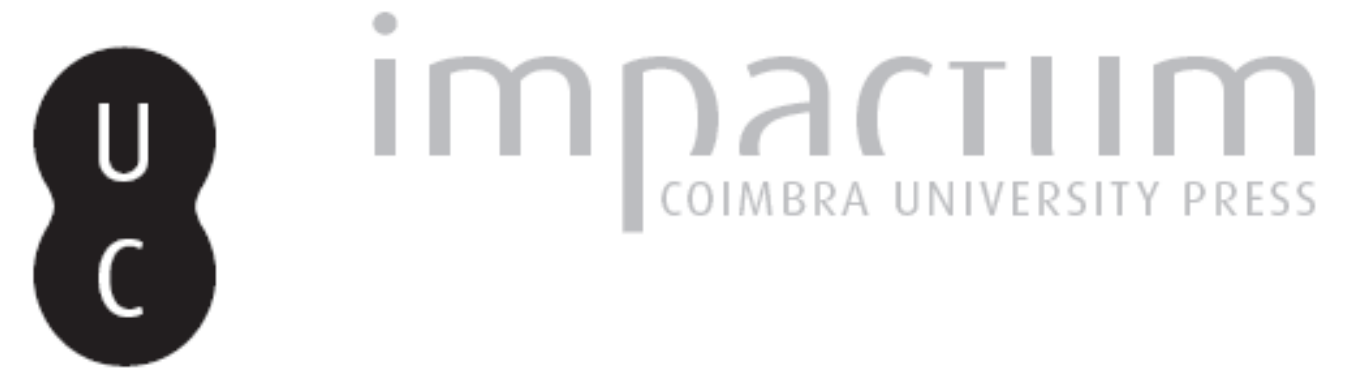

\title{
Panel analysis of the FDI impact on international trade revisited
}

Autor(es): Magalhães, Manuela; Africano, Ana Paula

Publicado por: Imprensa da Universidade de Coimbra

URL persistente:

URI:http://hdl.handle.net/10316.2/43509

DOI:

DOI:https://doi.org/10.14195/2183-203X_45_3

Accessed : $\quad$ 26-Apr-2023 08:35:38

A navegação consulta e descarregamento dos títulos inseridos nas Bibliotecas Digitais UC Digitalis, UC Pombalina e UC Impactum, pressupõem a aceitação plena e sem reservas dos Termos e Condições de Uso destas Bibliotecas Digitais, disponíveis em https://digitalis.uc.pt/pt-pt/termos.

Conforme exposto nos referidos Termos e Condições de Uso, o descarregamento de títulos de acesso restrito requer uma licença válida de autorização devendo o utilizador aceder ao(s) documento(s) a partir de um endereço de IP da instituição detentora da supramencionada licença.

Ao utilizador é apenas permitido o descarregamento para uso pessoal, pelo que o emprego do(s) título(s) descarregado(s) para outro fim, designadamente comercial, carece de autorização do respetivo autor ou editor da obra.

Na medida em que todas as obras da UC Digitalis se encontram protegidas pelo Código do Direito de Autor e Direitos Conexos e demais legislação aplicável, toda a cópia, parcial ou total, deste documento, nos casos em que é legalmente admitida, deverá conter ou fazer-se acompanhar por este aviso.

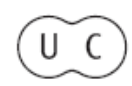




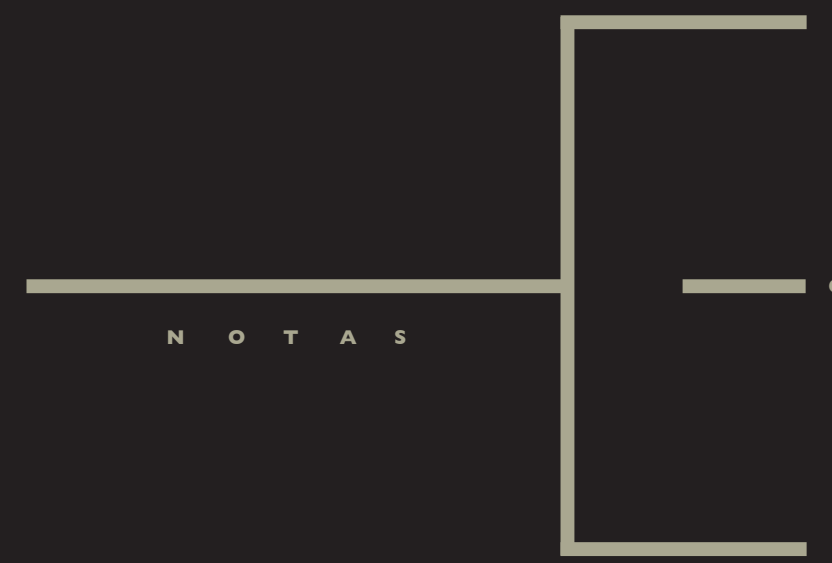

Helder Sebastião / António Portugal Duarte / Gabriel Guerreiro Where is the Information on USD/Bitcoin Hourly Prices?

ANA Fontoura GOUVEIA The Political Economy of Pension Systems with Low-Skilled Labor Mobility:A Cross-Country Analysis

Manuela Magalhães / Ana Paula Africano Panel Analysis of the FDI Impact on International Trade Revisited

Teresa Garcia / Paulo Vieira

O Mercado de Crédito Especializado ao Consumo em Portugal

JoÃo SOUSA ANDRADE As Reformas Monetárias e o Euro 


\title{
Panel Analysis of the FDi Impagt on International Trade Revisited \\ Manuela Magalhães \\ Ana Paula Africano
}

Received for publication: March 2, 2017 Revision accepted for publication: May 17, 2017

\begin{abstract}
This paper examines the relationship between Foreign Direct Investment (FDI) and international trade. Specifically, the relationship between the stock of outward FDI, and inward FDI and Imports and Exports in the Portuguese economy. This paper also studies some technical problems associated with panel data that have frequently been ignored in previous studies. And the problems of serial and contemporaneous correlation in particular can have a sizeable impact on estimates and statistical inferences. Our results show that there exist country-specific and time effects on the corrected panel data of heteroscedasticity and correlation and a substitutability relationship between imports and outward stock of FDI over the period 2000-2013.
\end{abstract}

Keywords: FDI; trade; gravity analysis; panel data.

JEL Classification: F1; F4.

Acknowledgement: We would like to thank the Editor for useful comments and suggestions that have improved the paper. A previous version of this paper circulated under the title "A panel analysis of the FDI impact on international trade." This revised version uses longer and updated data series. 


\section{INTRODUGTION}

In recent decades, international trade and foreign direct investment (FDI) have been the main engines of globalization. At the core of this process are the liberalization policies on trade and investment, on multilateral and bilateral/regional levels. Exports have grown much faster than GDP and FDI has grown at a faster pace than exports. This freer flow of goods, services and capital across-borders interconnect different economies, create interdependences and builds up economic integration. For policy making, it is important to have a good understanding of economic and social effects associate to trade and FDI, but also on their interactions.

The theoretical literature on trade and FDI is not conclusive on the existence of a substitution or a complementary relationship. References in the literature on trade models and in the literature on FDI demonstrate that, depending on the circumstances, FDI and trade may relate positively, as complements, as well as negatively, as substitutes. The empirical literature also indicates that FDI and trade may have a positive or negative relationship.

Over the last two decades, the Portuguese economy experienced strong shocks in international competitiveness. On the multilateral stage, competition increased substantially over two main events: the dismantling of the multi-fiber arrangement from 1995 to 2005 - under the Uruguay round - and the full admission of China into the WTO in 2001. On the European Union (EU) context, Portugal as a middle-low income economy experienced high competition pressure with the central and eastern European countries membership. These countries became competitors on both fields - in major Portuguese export markets and in attracting FDI from major investors. Additionally, as a founding member of the monetary union, the adoption of the common currency also intensified the competition within the Euro area.

Export indicators reveal an overall stagnant or deteriorating position: from 1995 to 2005, the ratio of exports of goods and services to GDP was stable at a value lower than $30 \%$; export performance in terms of market share was declining in the first years of the millennium. Yet, since 2010, both indicators show a strong positive trend: by 2015 total exports were around 40\% of GDP, with substantial gains in market share (OECD, 2017). Investment is crucial to sustain this recovery in exports, but since 2010 it has declined from $20.6 \%$ of GDP to $15.3 \%$ in 2015 . Moreover, investment has been substantially weaker than that observed in other economies in the Euro area, and its current level is more than $30 \%$ smaller its pre-crisis value (OECD, 2017). In this context FDI has a critical role to consolidate international competitiveness of Portuguese economy.

In the aftermath of the crisis in Portugal it is recognized that economic growth must be driven by exports and investment rather than domestic consumption. In these circumstances, it seems relevant to revisit how FDI relates to trade in this economy.

Sections 2 and 3 present a brief review of, respectively, theoretical models and empirical studies that examine the relationship between FDI and Trade. Section 4 illustrates our modelling strategy of a modified gravity equation in a panel data framework of Portuguese trade and FDI. The main estimated results are presented and discussed in section 5. Section 6 concludes our study. 


\section{Literature Review}

Traditionally, trade theories were developed in a framework that assumes international immobility of production factors. Yet, the activities of multinational enterprises have been growing since the Second World War and since the eighties multinational sales have been growing faster than trade in manufacturing. These growing flows and stocks of FDI could not be ignored by trade theories and as a result there was a stream of trade models that considered the existence of multinational enterprises along national enterprises. This was done within a variety of models that integrated the mode of foreign market access into the "new" trade theories. Overall, these models show that, depending on a variety of circumstances FDI and trade may have been complements as well as substitutes.

Foreign direct investment is the process by which a national firm has control/ ownership over a business located in other country, normally identified as an affiliate. By this way the national firm becomes a multinational enterprise (MNE). There are two structurally different types of FDI, depending on the way the MNE organizes its international business, namely horizontally or vertically. Horizontal FDI is normally associated with bilateral flows of investments between developed economies. In this case the parent company reproduces the whole process of production of goods and/or services in different countries. Vertical FDI means that the home company fragments the production process across different locations/countries according to their respective comparative advantages generating intra-firm trade. By this way, the parent company rationalises its production and aims to reduce costs and to obtain gains in terms of efficiency. Vertical investments are mostly present in FDI flows from developed to less developed economies and normally refer to less sophisticated stages of the production process such as assembling operations. Vertical FDI may also take place between developed economies but in more sophisticated stages of the production process.

Complementarity between trade and FDI is normally found in trade models that incorporate vertical foreign investment, meaning that the MNE fragments/splits the production process across countries in order to reduce costs. In these types of models (e.g. Helpman, 1984, and Grossman and Helpman, 1991), differences in relative factor endowments between countries and differences in factor intensities and specialization between sectors are determinants of both trade and the formation of multinationals. They are particularly useful to explain FDI from developed countries into developing economies. Helpman (2006) considers that the development in trade theory that address within-industry heterogeneity in terms of size and productivity revealed that only small fraction of firms are able to take foreign business. Exporters are bigger and have higher productivity than non-exporters, and, in turn, firms with foreign investments are bigger and more productive than exporters. Within this context, international fragmentation of production has become more complex, and so have the sourcing strategies of firms as well as integration strategies of MNEs.

Markusen (1984) shows that complementarity between FDI and trade is still possible when countries have identical endowments, preferences and technology, and multinationalisation occurs in the context of multi-plant economies of scale. His basic idea 
is the existence of firm/headquarter-specific activities which are distinct from plant-specific activities. Firm-specific activities are produced centrally at the headquarters, have a public good nature and generate firm-specific fixed costs. It includes activities such as R\&D, distribution, administration services, marketing. Plant-specific activities are associated with the production process and generate plant-specific fixed costs. One possible solution for the model is a multinational monopoly, in which headquarter activities concentrate in the home country and the production plant goes to the host country, originating bilateral trade - headquarter services in exchange for final goods.

Substitution between FDI and trade is found in models that assume horizontal investments, meaning that the MNE produces the same goods and services in different countries. This is the most common type of FDI and refers to bilateral investments between developed economies. Some trade models assume similarity between countries - in size, endowments and technology - plus economies of scale at the firm and plant-levels incorporating an endogenous formation of multiplant multinationals. This is the case of models by Hortsman and Markusen (1992), Brainard (1993) and Markusen and Venables (1998) and they admit alternative solutions depending, on the one hand, on the relative size of the firm and plant scale economies, and, on the other, on trade costs - transport costs plus barriers to trade and investment. In other words, the equilibrium - exporting or investing - depends on the trade-off between proximity to the market which reduces trade costs and the concentration of production which allows for a better exploitation of economies of scale. High transport costs and plant-scale economies favour horizontal FDI that may be associated with distinct equilibria.

Markusen and Venables (1998, 2000), Egger and Pfaffermayer (2002) also explore another avenue - the convergence hypothesis - to demonstrate that FDI and trade are substitutes. Starting with the assumption of asymmetry between countries they show that the convergence in terms of size, endowments and income increases the activities of MNEs. As multinational enterprises displace national enterprises the volume of trade decreases, meaning that FDI substitutes trade. Finally, trade models by Markusen (1997, 2000) and Carr et al. (2001) admit both vertical and horizontal FDI and consequently find solutions that admit both complementarity as well as substitution between FDI and trade.

The international business literature typically looks at FDI and trade as alternative entry modes into foreign markets. Still, Dunning (1998) considers that the relation between trade and FDI may vary depending on the kind of trade and FDI analyzed and the conditions under which they occur, while Gray (1998) explicitly admits that production affiliates that are market seeking reduce trade whereas production affiliates that are efficiency seeking increase trade. In the former case, trade and FDI are substitutes and in the latter they are complements.

\section{EMpirical Studies}

The particular question on whether FDI and trade are substitutes or complements has produced some empirical research without a definite result. Despite the strong 
theoretical foundations for a substitute relation between FDI and trade this result has been found in few empirical studies (e.g. Frank and Freeman, 1978, Cushman, 1988, and Blonigen, 2001), while complementarity has been the most common result.

Most empirical research on this topic has looked for how changes in FDI correlate to changes in trade and vice versa. In other words, they have questioned whether systematic changes in FDI are related to systematic changes in trade, in particular if trade and FDI are substitutes (negative correlation) or complementary (positive correlation). These studies have not questioned or studied the direction of causality between FDI and trade and this seems to be a general limitation. As we will see below contrasting results are associated with the diversity of interactions that exist between FDI and trade, but also with different perspectives of analysis (e.g. country, industry, and firm).

At the country level, as suggested by Fontagné (1999), the links between trade and FDI can be seen from three different perspectives: the investing or home country, the recipient or host country and third countries. For the investing country FDI can be a substitute for trade to the extent that exports are replaced by local sales by the affiliates in foreign markets. On the other hand, FDI may also be complementary to trade to the extent that induces intra-firm trade in intermediate and final goods (e.g. headquarter services). In the former case investing abroad will have a negative impact on production, employment and trade balance in the home country, while in the latter case will have a positive impact. In the case of the host country the argument is symmetrical to that of the investor and therefore inward FDI may have a complementary or substitute relation with trade. Again the effects on domestic production, employment and the balance of trade (current account) can be diverse. Third economies may also affect, and be affected by, the relationship between FDI and trade, to the extent that foreign affiliates in these countries develop new trade relations with the affiliates in the host country and vice-versa.

At country level studies by Grubert and Mutti (1991), Blomstrom and Kokko (1994), Eaton and Tamura (1994), Brenton et al. (1999), Clausing (2000), and Hejazi and Safarian (2001) have found that FDI and trade are complementary. Several studies use the gravity model with success. For example, Grubert and Mutti (1991) examine how FDI relates to exports and imports for the United States, using trade flows with 33 counties in 1982. The study finds complementarity between FDI and both imports and exports on a bilateral basis. However, the authors suggest that a clear-cut conclusion needs a multilateral-country study. Clausing (2000) uses a panel data approach and studies the interaction between outward FDI and exports in the United States in her relation with 29 countries. He also studies the relationship between inward FDI into the US and American imports and uses gravity equations to find complementarity between trade and FDI. In another country study, Lafourcade and Paluzie (2011) study the impact of European integration on the geography of trade of French regions and FDI. They find that border regions with Spain and Italy experienced a decline in trade with neighboring countries, in contrast with all other border regions. The authors point the decline in the propensity of Spanish and Italian affiliates in these regions to trade with the respective home country, suggesting a substitution effect between FDI and trade. 
Martinez et al. (2012) use a multilateral approach to study the impact of EU market integration (i.e. the reduction of trade barriers among EU members) on flows of trade and FDI. Using a gravity equation their results suggest that FDI and trade are complements as they reinforce each other. This effect is valid for intra-EU FDI, but also for FDI originated in third countries. They also point that access to market share is more relevant than access to costs-differentials suggesting that horizontal FDI prevail over vertical FDI.

Micro (firm)-level studies allow for a better understanding on the complex interlinks between trade and FDI. However, this approach requires detailed data bases about firm's decisions on production, sales and investment which are not extensively available. Baldwin and Okudo (2013) develop a study based on detailed information about Japanese affiliates around the world. They find clear evidence that Japanese multinationals have mixed motivations for FDI and their affiliates are partly vertical and partly horizontal. This pattern is observed across sectors and countries. They found that whereas affiliates in North America were more horizontal, in Europe and Asia they were more vertical. In the latter case networked FDI prevail as firms are seen as part of a regional production network. They also found that overall from 1996 to 2005 affiliates became more vertical across sectors and countries. Within the multiple combinations that affiliates follow on sourcing for intermediates and output sales there is scope for both complement and substitution effects between trade and FDI.

\section{The Econometric Model}

Our objective is to estimate the relationship between trade and FDI in the Portuguese economy. The empirical analysis applies a modified gravity equation to a panel of annual observations of Portuguese exports to and imports from 27 countries over a period of 14 years (2000-2013). Two different equations are estimated one for exports and the other for imports.

The gravity equation estimated is the following:

$$
\begin{aligned}
T_{i t}= & \beta_{0}+\beta_{1} \text { GDP }_{i t}+\beta_{2} \text { DIST }_{i}+\beta_{3} \operatorname{Lang}_{i}+\beta_{4} \text { Bord }_{i}+\beta_{5} \text { TFDIin }_{i t}+ \\
& \beta_{6} \text { TFDIout }_{i t}+u_{i}+\theta_{t}+v_{i t},
\end{aligned}
$$

for $i=1, \ldots, \mathcal{N}, t=1, \ldots, \mathcal{T}$, where $T_{i}$ indicates the imports/exports between Portugal and country $i, G D P_{i}$, denotes the corresponding Gross Domestic Product. DIST $i$ is the great circle distance between capital of country $i$ and capital of Portugal (Lisbon). $\operatorname{Lang}_{i}$ and Bord $_{i}$ are dummy variables and take the value one when the country $i$ has the same language or has a common border with Portugal. TFDIin $i$ and TFDIout $i$ are the transformed variables of the FDI stock of country $i$ in Portugal (TFDIin) and the FDI stock of Portugal in country $i$ (TFDIout).

In our specification, we apply a two-way model that incorporates a time-specific effect $\left(\theta_{t}\right)$ and a country-specific effect $\left(u_{i}\right) \cdot v_{i t}$ is the idiosyncratic error. 
All variables except dummy variables are in logs. As the model is log-linearised the problem appears with zero or negative values. To avoid this problem we transform the FDI stock variable. ${ }^{1}$ This study uses the stock of FDI as an explanatory variable of trade flows which has several advantages in relation to the alternative inclusion of FDI. First, the stock variable avoids problems of multicollinearity between trade and investment flows, given that such flows are simultaneously affected by the same economic variables. Second, this approach is more correct because FDI flows do have an impact on trade with a time lag. Therefore, the use stocks is able to capture these lagged effects which is not possible with flows. Third, the stock of FDI gives a more accurate measure of foreign investment in the economy and as such the extent to which it facilitates or obstructs trade flows.

Since individual effects are included in the model, we have to decide whether they are treated as fixed or random. If $u_{i}$ is treated as a random variable we have the called random effect model. In this case $u_{i} \sim i i d\left(0, \sigma_{u}^{2}\right), v_{i t} \sim \ddot{i i d}\left(0, \sigma_{v}^{2}\right)$ and $u_{i}$ are independent of $v_{i t}$. In addition, the explanatory variables are independent of $u_{i}$ and $v_{i t}$ for all $i$ and $t$ (Baltagi, 1995). Otherwise, if $u_{i}$ are assumed to be fixed parameters to be estimated and the remaining disturbances stochastic with $v_{i t}$ independent and identically distributed iid $\left(0, \sigma_{v}^{2}\right)$, then the explanatory variables are assumed independent of $v_{i t}$ for all $i$ and $t$. In this case, FEM is applied. ${ }^{2}$

We estimate a two-way FEM and a two-way REM, where all variables, except dummy variables, are in logarithms. After, we determine Hausman's $\chi^{2}$ statistic for testing random versus fixed effects. Whether the REM or the FEM is the econometrically more appropriate depends on the correlation of the individual effects with the regressors. REM assumes that there is no such correlation.

The application of OLS to data characterised by nonspherical errors produces inefficient coefficient estimates and the corresponding errors estimates are biased. The application of GLS produces coefficient and standard errors estimates that are efficient

1 The larger desinvestment in our sample is - 83000 . So, we divided all observation of FDI stock by 83000 (ratio: fdi/83000). Therefore, all values of transformed FDI stock are greater than -1 . After we add one to the ratio and $\log$-linearised it:

TFDIin $_{i t}=\ln \left(1+\right.$ TFDIin $\left._{i t} / 83000\right)$,

TFDIout $_{i t}=\ln \left(1+\right.$ TFDIout $\left._{i t} / 83000\right)$.

This transformation of FDI stock does not change its values. If:

FDI $<0 \Rightarrow\left(1+\frac{F D I}{8300}\right)<1 \Rightarrow \ln \left(1+\right.$ TFDIin $\left._{i l} / 83000\right)<0 ;$

FDI $=0 \Rightarrow\left(1+\frac{F D I}{8300}\right)=1 \Rightarrow \ln \left(1+\right.$ TFDIin $\left._{i l} / 83000\right)<0$; and

FDI $>0 \Rightarrow\left(1+\frac{F D I}{8300}\right)>1 \Rightarrow \ln \left(1+\right.$ TFDIin $\left._{i t} / 83000\right)<0$.

2 The FEM does not allow directly to estimate time-invariant variables. 
and unbiased, respectively, assuming that the errors covariance structure is correctly specified and its elements known.

Becky and Katz (1995) have studied an error covariance structure characterised by groupwise heteroscedasticity, first-order serial correlation and cross-sectional, or spatial correlation and they have used the Monte Carlo analysis to compare FGLS with OLS, where OLS standard errors are corrected for the three categories of nonspherical disturbances. They have called their estimator OLS with panel corrected standard errors (PCSE). Their study shows that FGLS consistently underestimates standard errors, concluding that OLS with PCSE is superior to FGLS, and recommend its use.

\section{Results}

In this section the estimation procedures follow two sequential stages. First, we start with a robust pooled data estimation (ROLS), a fixed effects model (FEM) and a random effects model (REM) estimation. Given the nature of panel data, we test the hypothesis of groupwise heteroscedasticity and correlation (serial or contemporaneous) in both. As the null hypothesis is rejected, in the second stage we correct the panel for heteroscedasticity and correlation. This is done with PCSE and feasible GLS and in order to deal with unobservable fixed effects, the first differences are estimated by PCSE, FGLS and robust OLS. This procedure is followed separately for exports and imports.

\subsection{EXPORTS}

The OLS ${ }^{3}$ estimation does not take into account that the error structure may not conform to OLS assumptions, and to overcome this we use the White estimator of variance (Table 1, first column). The OLS model explains a large part of the variance of Portuguese exports $\left(R^{2}=0.84\right)$. All variables, except language and border are statistically significant. These results suggest that Portuguese exports to Spain and Brazil are not encouraged or discouraged by their common border or language, respectively. In relation to Spain, it is worth mentioning that Portugal has a shorter period of market integration with Spain - only since 1986 when both become EU members. In contrast, with other EU economies strong trade relations exist since the earlier 1960s when Portugal become an EFTA member. As for the FDI-trade hypothesis, the result suggests a strong complementary relation between FDI and Portuguese exports.

However, as mention above, the OLS model does not take into account individual effects and we believe in the existence of individual effects apart from distance, language and border. Thus, we have done the Breusch and Pagan test $\left(L M_{B P}=753.55\right)$ that has confirmed our suspicion. Next, we have estimated the model using fixed-

3 The missing values of the inward and outward FDI were removed and we have used a transformed variable of FDI to avoid problems with the logarithm of null and negative values. 
-effects ${ }^{4}$ and random-effects, but the Hausman test reveals that REM does not obtain consistent parameter estimates suggesting the existence of individual fixed effects.

Despite the conclusion on the existence of fixed effects, all variables in the FEM, except the variable GDP, are statistically insignificant. This fact can be associated with the violation of the homocedasticity hypothesis across countries. Therefore, we have tested for groupwise likelihood ratio heteroscedasticity in fixed effect model and the result was that the null hypothesis of homocedasticity across countries is rejected $\left(G W: \chi^{2}(23)=9,819.97\right)$. This limitation can be overcome with the adoption of a feasible GLS estimator or a PCSE with a general variance matrix that incorporates heteroscedasticity across countries.

Finally, we have tested for serial correlation and contemporaneous correlation in our fixed effect model and have found evidence of autocorrelation. For the FEM presented in column (3) of Table 1 we reject the null hypothesis of no first-order autocorrelation $(\mathrm{F}(1,23)=104.298)$ generated by AR process and we conclude that there exists contemporaneous correlation.

Given the results of the heteroscedasticity and autocorrelation tests, we have decided to apply the feasible GLS (FGLS) and PCSE estimator, corrected of country groupwise heteroscedasticity and contemporaneous correlation.

The FGLS is a method developed by Parks-Kmenta that uses GLS estimation and we have corrected it for first serial correlation in the residuals, contemporaneous correlation and heteroscedasticity. The PCSE method was developed by Beck-Katz and incorporates also these corrections. However, we need one process that takes into account individual effects, heteroscedasticity and correlation and that produces consistent estimates. One way to do this is by differentiating the equation 1 which allows the removal of fixed effect and eliminates the autocorrelation. Therefore, we estimated the first difference model by PCSE and FGLS controlling heteroscedasticity and contemporaneous correlation and by OLS with a robust variance-covariance matrix.

The results reported in columns 4, 5 and 6 in Table 1 point to the conclusion that Portuguese exports are positively determined by market dimension. The presence of foreign affiliates in the Portuguese economy has no statistically significant effect on the Portuguese exports during the period 2000-2013. In other words the stock of inward/ outward FDI does not seem to be trade creating. This result suggests that the stock of foreign investments in the Portuguese economy does not work as a channel through which exports expand. Thus, for the period 2000-2013 we did not find the complementarity relationship between FDI and Exports as it was found by Africano and Magalhães (2005) and Magalhães and Africano (2007) for the period 1995-2000. One explanation is the different period of analysis, where now the significance of inward FDI is replaced by the significant positive time effects which may reflect the effect of higher integration of the Portuguese economy in the EU and the small size of the Portuguese economy being the Portuguese exports only determined by the dimension of the other countries' GDP and time effects. Another explanation may be a change in the composition of the inward FDI. If the inward FDI is now directed to finance services there is no reason to

4 The FEM incorporates both country and time effects. 
Notas Económicas

Dezembro '17 (49-64)

Table 1: Estimation results for Exports

\begin{tabular}{|c|c|c|c|c|c|c|}
\hline & (1) & $(2)$ & (3) & $(4)$ & (5) & (6) \\
\hline Variables & ROLS & FEM & REM & FD-PCSE & FD-ROLS & FD-FGLS \\
\hline \multirow[t]{2}{*}{ GDP } & $0.860^{* * *}$ & $1.034^{* * *}$ & $0.955^{* * *}$ & $1.758^{* * *}$ & $1.758^{* * *}$ & $1.758^{* * *}$ \\
\hline & (28.65) & $(3.47)$ & $(9.66)$ & (3.24) & $(4.13)$ & $(5.14)$ \\
\hline \multirow[t]{2}{*}{ Dist } & $-0.000319^{* * *}$ & & $-0.000337^{* * *}$ & & & \\
\hline & $(-16.64)$ & & $(-5.43)$ & & & \\
\hline \multirow[t]{2}{*}{ Lang } & -0.229 & & -0.0829 & & & \\
\hline & $(-1.23)$ & & $(-0.12)$ & & & \\
\hline \multirow[t]{2}{*}{ Bord } & 0.122 & & $1.305^{*}$ & & & \\
\hline & $(0.73)$ & & $(1.82)$ & & & \\
\hline \multirow[t]{2}{*}{ TFDIin } & $6.607^{* * *}$ & 0.314 & 0.769 & 0.744 & 0.744 & 0.744 \\
\hline & $(5.55)$ & $(0.42)$ & $(1.02)$ & $(0.92)$ & $(1.06)$ & $(0.72)$ \\
\hline \multirow[t]{2}{*}{ TFDIout } & $0.106^{* *}$ & -0.00545 & 0.00604 & 0.00226 & 0.00226 & 0.00226 \\
\hline & $(2.53)$ & $(-0.22)$ & $(0.24)$ & $(0.26)$ & $(0.24)$ & $(0.14)$ \\
\hline \multirow[t]{2}{*}{ Constant } & $2.288^{* * *}$ & -1.053 & 1.128 & 0.0166 & 0.0166 & 0.0166 \\
\hline & $(6.16)$ & $(-0.27)$ & $(0.91)$ & $(0.36)$ & $(0.86)$ & $(0.93)$ \\
\hline$R^{2}$ & 0.84 & & & 0.13 & 0.13 & \\
\hline Obs. & 252 & 252 & 252 & 183 & 183 & 183 \\
\hline Hausman: $\chi^{2}(13)$ & & & $9.87 * *$ & & & \\
\hline $\mathrm{F}(3,216)$ & & $14.07 * * *$ & & & & \\
\hline Wald $\chi^{2}(k-1)$ & & & $613.14^{* * * *}$ & $12.71 * * *$ & & $1340.88 * * *$ \\
\hline $\mathrm{GW} \chi^{2}(i)$ & & $9819.97 * * *$ & & & & \\
\hline $\mathrm{F}(1,22)$ & & $104.298 * * *$ & & & & \\
\hline$L M_{B P}: \chi^{2}(1)$ & & & $753.55^{* * * *}$ & & & \\
\hline
\end{tabular}

Notes: $* * *, * *$, and $*$ denotes significance at the $1 \%, 5 \%$, and $10 \%$, respectively. Standard deviation in brackets. 
increase exports. The Portuguese investments abroad also have a statistically insignificant effect on the Portuguese exports as in the previous studies (Africano and Magalhães, 2005, and Magalhães and Africano, 2007).

\subsection{IMPORTS}

Table 2 presents the results of the robust OLS, fixed effects and random effects estimator. Here the missing values of inward and outward FDI were also dropped and the OLS estimates were obtained using the White estimator of variance. The OLS model explains a large part of the variance of Portuguese imports $\left(R^{2}=0.74\right)$ that is determined by market dimension (0.635), distance (-0.000241), language (0.46), border (0.741), inward FDI (6.176) and outward FDI (0.117). The inward and outward FDI stock have a positive and significant effect on Portuguese imports which places emphasis on the relationship of complementarity between imports and inward FDI when we are taking pool data into account. Portugal imports above "normal" from Spain and Brazil, given that language and border variables are statistically significant.

We have followed the same procedure as in the previous section for exports and we test for the existence of individual heterogeneity, and the existence of heteroscedasticity and autocorrelation, and contemporaneous correlation in our model of imports. The groupwise likelihood test shows that the disturbances $(\mathrm{GW}=3198.67)$ are heteroscedastic. Additionally, they are also serially correlated $(\mathrm{F}(1,22)=11.337)$ and contemporaneous correlated, invalidating the statistic inference.

So, in order to have consistent estimates and consider the existence fixed effects they were removed by differentiating the model with the first differences model, which amounts to build model (1) in the variables first differenced. Thus, we estimate first difference with pooled robust OLS, PCSE and FGLS.

Columns 4, 5 and 6 in Table 2 show that Portuguese imports are positively determined by market dimension and negatively determined by the stock of outward FDI. The stock of foreign investments abroad has a negative and statistically significant correlation with Portuguese imports. This result suggests that there is a substitutability relation between the stock of outward FDI and Portuguese imports. Thus, for the period 2000-2013 Portuguese affiliates in the exterior act as a substitute channel for imports reducing the Portuguese imports. This substitute relationship is found for Austria, Brazil, Canada, Czech Republic, Finland, Greece, Iceland, Japan, Mexico, Norway and USA. Yet inward FDI is not statistically significant which reveals that foreign affiliates in Portugal have no impact on Portuguese imports.

\section{Gonclusion}

This paper examines the relation between FDI stock (inward and outward) and Portuguese trade flows. In this paper we have applied a panel data analysis, to Portuguese trade flows with 23 trade partners over the 2000-2013 interval. The gravity model was 
Notas Económicas

Dezembro '17 (49-64)

Table 2: Estimation results for Imports

\begin{tabular}{|c|c|c|c|c|c|c|}
\hline & (1) & (2) & (3) & $(4)$ & (5) & (6) \\
\hline Variables & ROLS & FEM & REM & FD-PCSE & FD-ROLS & FD-FGLS \\
\hline \multirow[t]{2}{*}{ GDP } & $0.635^{* * *}$ & 0.443 & $0.681^{* * *}$ & $2.119^{* * *}$ & $2.119^{* * *}$ & $2.119^{* * *}$ \\
\hline & $(17.14)$ & $(1.43)$ & $(5.76)$ & $(3.97)$ & $(4.33)$ & $(4.83)$ \\
\hline \multirow[t]{2}{*}{ Dist } & $-0.000241^{* * *}$ & & $-0.000250^{* * *}$ & & & \\
\hline & $(-9.92)$ & & $(-3.31)$ & & & \\
\hline \multirow[t]{2}{*}{ Lang } & $0.460^{* *}$ & & 0.682 & & & \\
\hline & $(2.13)$ & & $(0.79)$ & & & \\
\hline \multirow[t]{2}{*}{ Bord } & $0.741^{* * *}$ & & $1.912^{* *}$ & & & \\
\hline & $(3.57)$ & & $(2.19)$ & & & \\
\hline \multirow[t]{2}{*}{ TFDIin } & $6.176^{* * *}$ & 0.780 & 1.089 & 0.937 & 0.937 & 0.937 \\
\hline & $(4.08)$ & $(1.00)$ & $(1.40)$ & $(0.51)$ & $(0.46)$ & $(0.71)$ \\
\hline \multirow[t]{2}{*}{ TFDIout } & $0.117^{* *}$ & -0.00407 & 0.00337 & $-0.0464^{* * *}$ & $-0.0464^{* * *}$ & $-0.0464^{* *}$ \\
\hline & $(2.32)$ & $(-0.16)$ & $(0.13)$ & $(-3.26)$ & $(-3.21)$ & $(-2.25)$ \\
\hline \multirow[t]{2}{*}{ Constant } & $5.465^{* * *}$ & $7.300^{*}$ & $4.913^{* * *}$ & 0.00327 & 0.00327 & 0.00327 \\
\hline & $(12.01)$ & $(1.78)$ & $(3.30)$ & $(0.08)$ & $(0.14)$ & $(0.14)$ \\
\hline$R^{2}$ & 0.74 & 0.40 & & 0.13 & 0.13 & \\
\hline Obs. & 252 & 252 & 252 & 183 & 183 & 183 \\
\hline Hausman: $\chi^{2}(13)$ & & & $49.03^{* * * *}$ & & & \\
\hline $\mathrm{F}(3,216)$ & & 1.03 & & & & \\
\hline Wald $\chi^{2}(k-1)$ & & & $197.79 * * *$ & $31.39 * * *$ & & $3510.83^{* * *}$ \\
\hline $\mathrm{GW} \chi^{2}(i)$ & & $3198.67^{* * * *}$ & & & & \\
\hline $\mathrm{F}(1,22)$ & & $11.337 * * *$ & & & & \\
\hline$L M_{B P}: \chi^{2}(1)$ & & & $753.55^{* * *}$ & & & \\
\hline
\end{tabular}

Note: See notes to Table 1. 
used to test the hypothesis of complementarity or substitutability on a panel analysis. Besides examining the type of relationship between FDI and trade flows, we also investigated the error structure and applied consistent estimation methods that take into account fixed effects associated to unobserved country effects.

We find a substitute relationship between outward FDI and imports when the residuals are corrected and PCSE, FGLS and robust OLS estimation method are applied to first differences. For the period under analysis, inward stock of FDI has no significant effect on trade. This suggests that foreign investments in the Portuguese economy have a neutral impact on trade balance. Yet, Portuguese affiliates act as a substitute of imports which favours the Portuguese trade balance. Nevertheless, studies at a lower level of aggregation should be carried out to better understand the effects of FDI on trade at sector level. At lower level of aggregation, positive balance effects in some sectors may cancel out negative balance of trade in other sectors leading, at aggregate level, at no significance of inward FDI on trade.

Portuguese investments abroad, as shown in both regressions, have no impact on exports which to some extent is not surprising. Such investments are relatively small in value and highly concentrated in just two markets: Spain and Brazil. Moreover, in the latter case investments were primarily directed to the privatisation of non-tradable services. Regarding outward FDI, although we have not found the substitute relationship between outward FDI and Exports when we correct for serial and contemporaneous correlation as in Fonseca et. al. (2010), we found a substitute relationship between outward FDI and imports which is particular relevant for countries such Japan, Greece, Finland, and Austria.

The policy implications of these results are not totally clear. On the one hand, policies designed to help the internationalization of Portuguese companies' through FDI did not improve the external competitiveness of the Portuguese economy as measured by exports. On the other hand, our results suggest these policies may at least contribute to diminish the weight of imports on trade balance.

This question may be clarified by studying the effects of FDI on trade at sectorial level that would provide greater insights into this relationship. Moreover, a sample with a longer time period might be a condition to capture the impact that changes in external trade conditions have on Portuguese trade. These could be changes in the EU external trade policy on a bilateral level or at multilateral level in the WTO.

\section{REFERENGES}

Africano, A.; Magalhães, M. (2005) FDI and trade in Portugal: A gravity analysis, FEP Working Papers 174.

Baldwin, R.; Okubo, T. (2014) Networked FDI: Sales and sourcing patterns of Japanese foreign affiliates, World Economy, 37, 1051-1080.

Beck N.; Katz J. N. (1995) What to do with time series cross section data, American Political fournal Review, 89, 634-647. 
Blomstro“m, M.; Kokko, A. (1994) Home country effects of foreign direct investment: Evidence from Sweden, NBER Working Paper No. 4639.

Blonigen, B. (2001) In search of substitution between foreign production and exports, fournal of International Economics, 53 (1), 81-104.

Brainard, S. L. (1993) A Simple theory of multinational corporations and trade with a trade-off between proximity and concentration, NBER working paper No. 4269.

Brainard, L. (1997) An Empirical assessment of the proximity-concentration trade-off between multinational sales and trade, American Economic Review, 87 (4), 520-544.

Brenton, P.; Di Mauro, F.; Lu“cke, M. (1999) Economic integration and FDI: An empirical analysis of foreign investment in the EU and in Central and Eastern Europe, Empirica, 26 (2), 95-121.

Carr, D.; Markusen, J.; Maskus, K. (2001) Estimating the knowledge-capital model of the multinational enterprise, American Economic Review, 91 (3), 693-708.

Clausing, K. (2000) Does multinational activity displace trade? Economic Inquiry, 38 (2), 190-205.

Gushman, D. O. (1988) Exchange rate uncertainty and foreign direct investment in the United States, Weltwirtschaftliches Archiv, 124 (2), 322-336.

Dunning, J. H. (1998) The European internal market program and inbound foreign direct investment, in J. H. Dunning (ed.), Globalization Trade and Foreign Direct Investment, Oxford, Elsevier, 49-115.

Eaton, J.; Tamura, A. (1994) Bilateralism and regionalism in Japanese and US Trade and direct foreign investment patterns, Fournal of Fapanese and International Economies, 8, 478-510.

Egger, P. and Pfarffermayr, M. (2002) Foreign direct investment and European integration in the 90's, Working Papers in Economics, University of Innsbruck.

Fonseca, M.; Mendon,ca, A.; Passos, J. (2010) Home country trade effects of outward FDI: An analysis of the Portuguese case, 1996-2007, FEP Working Papers 365.

Fontagné, L. (1999) Foreign direct investment and international trade: Complements or substitutes, STI Working Papers.

Frank, R. H.; Freeman, R. T. (1978) Distributional Consequences of Direct Foreign Investment, New York, Academic Press.

Gray H. P. (1998) International trade and foreign direct investment: the interface, in J. H. Dunning (ed.), Globalization Trade and Foreign Direct Investment, Oxford, Elsevier, 19-27.

Grossman, G.M.; Helpman, E. (1991) Innovation and Growth in the Global Economy, Cambridge, MIT Press.

Grubert, H.; Mutti, J. (1991) Taxes, tariffs and transfer pricing in multinational corporations, Review of Economics and Statistics, 73, 285-293.

Head, K.; Ries, J. (2001) Overseas investment and firm exports, Review of International Economics, 9 (1), 108-122.

Hejazi, W.; Safarian, A.E. (2001) The complementarity between U.S. foreign direct investment stock and trade, Atlantic Economic Fournal, 29 (4), 420-438.

Helpman, E. (1984) A simple theory of trade with multinational corporations, fournal of Political Economy, 92, 451-71.

Helpman, E. (2006) Trade, FDI, and the organization of firms, Fournal of Economic Literature, 589-630.

Horstmann, I.; Markusen, J. (1992) Endogenous market structures in international trade, fournal of International Economics, 32, 109-129.

Lafourcade, M.; Paluzie, E. (2011) European integration, foreign direct investment (FDI), and the geography of French trade, Regional Studies, 45 (4), 419-439. 
Lipsey, R. E.; Ramstetter, E. D.; Blomstrom, M. (2000) Outward FDI and parent exports and employment: Japan, the United States, and Sweden, NBER Working Paper No. 7623.

Magalhães, M.; Africano, A. P. (2007) A panel analysis of the FDI impact on international trade, FEP Working Papers 235.

Markusen, J. (1984) Multinationals, Multi-plant Economies, and the Gains from Trade, fournal of International Economics, 16, 205-226.

Markusen, J. (1997) Trade versus Investment Liberalization, NBER Working Paper No. 6231. Markusen, J. (2000), Foreign direct investment and trade, CIES-Policy DP 0019.

Markusen, J.; Venables, A. (1998) Multinational firms and the new trade theory, Fournal of International Economics, 46 (2), 183-203.

Markusen, J.; Venables, A. (2000) The theory of endowment, intra-industry and multinational trade, Fournal of International Economics, 52 (2), 209-234.

Martínez, V.; Bengoa, M.; Sánchez-Robles, B. (2012) Foreign direct investment and trade: Complements or substitutes? Empirical evidence for the European Union, Technology and Investment, 3 (2), 105-1 12.

Mátyás, L. (1998) The gravity model: Some econometric considerations, World Economy, 21, 397-401.

Mouton, B. R. (1986) Random group effects and the precision of regression estimates, fournal of Econometrics, 32, 385-397.

Mouton, B. R. (1987) Diagnostic for group effects in regression Analysis, fournal Business and Economic Statistics, 5, 685-693.

Mucchielli, J.; Chédor, S.; Soubaya, I. (2000) Investissements directs à l'Étranger des multinationales fran, caises et relations commerciales avec leurs filiales: Une analyse sur donn'ees individuelles d'entreprises, Révue Économique, 51, 747-760.

Nunziata, L. (2000) Stata command for a likelihood ratio test for groupwise heteroscedasticity. (http:// www.nuff.ox.ac.uk/users/nunziata/software)

OECD (2017) OECD Economic Surveys: Portugal, Paris, OECD.

Pfarffermayr, M. (1996) Foreign outward direct investment and exports in Austrian manufacturing: Substitutes or complements? Weltwirtschaftliches Archiv, 132 (3), 501-521. 


\section{Appendix: Data sources}

In order to test the relationship between trade and FDI in the Portuguese economy we use a sample of OECD countries and Brazil, observed from 2000 to 2013. Values of Portuguese bilateral trade were taken from the OECD Statistical directory in current USD. These values were converted into the 1000 base year prices through the consumer price index from the International Financial Statistics. Only the trade in goods is included, meaning that trade in services is not taken into account in this study.

GDP values were obtained from the GDP per capita and population values from the Penn world table (PWT 9.0). The GDP in purchase power parity of 2000, and values for the other years were calculated with the Chain index. Inward and outward FDI are from the OECD International Direct Investment Database, in millions of Escudos, and then converted to USD with the yearly average exchange rate from the International Monetary Fund, International Financial Statistics CD-ROM. The variable distance is measured in kilometers and refers to the great circle distance between Lisbon and each capital of the countries included in the sample. 